\title{
APPLICATION OF FUZZY LOGIC IN THE GAS TRANSPORTATION CONTROL SYSTEM
}

\author{
Bobirjon Shomirzaev \\ Senior Lecturer \\ Andijan Machine-Building Institute \\ Republic of Uzbekistan \\ E-mail: shobabur@mail.ru
}

\section{ПРИМЕНЕНИЕ НЕЧЕТКОЙ ЛОГИКИ В СИСТЕМЕ УПРАВЛЕНИЯ ТРАНСПОРТОМ ГАЗА}

Шомирзаев Бобиржсон Уринбаевич

ст. преподаватель

Андижанский машиностроительный институт

Республика Узбекистан

\begin{abstract}
The article deals with the problem of automating the control of technological parameters of gas transportation using fuzzy logic. An information model and a system of differential equations for the flow of natural gas through a pipeline are presented. To simplify calculations, it is proposed to use a triangular membership function, for all fuzzy values

\section{АННОТАЦИЯ}

В статье рассматривается задача автоматизации управления технологическими параметрами транспортировки газа с применением нечеткой логики. Приведены информационная модель и система дифференциальных уравнений течение природного газа по трубопроводу. Для упрощения вычислений предложено применение треугольной функции принадлежности, для всех нечетких значений
\end{abstract}

Keywords: hydraulic resistance, gas transmission system, natural gas, membership function, transportation.

Ключевые слова: гидравлическое сопротивление, газотранспортная система, природный газ, функция принадлежности, транспортировка.

\section{Introduction}

In the global gas industry, in particular, in the field of storage and transportation of gas, research is being carried out to improve existing technologies, increase production efficiency and the capacity of technological units. Much attention is paid to the solution of theoretical problems of parametric identification and adaptive control of technological processes in conditions of uncertainty and their practical application in various fields [1].

Currently, the Republic of Uzbekistan pays great attention to automation and control of technological processes and industries, including the creation of advanced control systems that save energy and resources in the automation and management of gas storage and transportation [1].

The complexity of technologies for storage, transportation and treatment of gas and gas condensate requires the development of highly efficient methods and algorithms for controlling technological processes in conditions of uncertainty using the achievements of modern information technologies and technical means. In this regard, it is necessary to develop a control system with computer technologies for the preparation, storage and transportation of natural gas, which will allow analyzing technological solutions at a qualitatively new level and monitoring the main indicators of production, storage and transportation of gas and gas condensate [2].

\section{Research Methods and the Received Results}

Mathematical modeling of the processes of trunk transportation of natural gas is significantly complicated due to the presence of uncertainties in the initial data.

The uncertainty of the initial data can be taken into account in mathematical models using two types - probabilistic models, as well as taking into account the methods of the theory of fuzzy sets [2].

The uncertainty of some parameters of gas production systems is rather ambiguous from the point of view of probability and, accordingly, can be described in the form of fuzzy sets, which are also called fuzzy numbers. The actual drag coefficients of gravity pipes are usually close to the design values, but both also differ from them due to the error in calculating the impact and gravity resistance on the inner walls [3].

The most important task of developing an intelligent control system is not only the collection of relevant information, but also the selection or creation of effective models for demonstrating knowledge, which will allow it to be effectively processed in the decision-making process. This task is directly related to the development of highly efficient algorithms for modeling, predicting and adapting the parameters of the control system operating under conditions of uncertainty to create an appropriate knowledge base that includes the necessary information 
about the problem area and decision-making methods in this area.

The tasks of mathematical modeling of the processes of storage and transportation of natural gas are significantly complicated by the presence of uncertainty in the initial data.
To simulate the processes of storage and transportation of gas, one has to use fuzzy information about the state and characteristics of wells, pipelines and electrical equipment [3].

The information model is shown in Fig. 1.

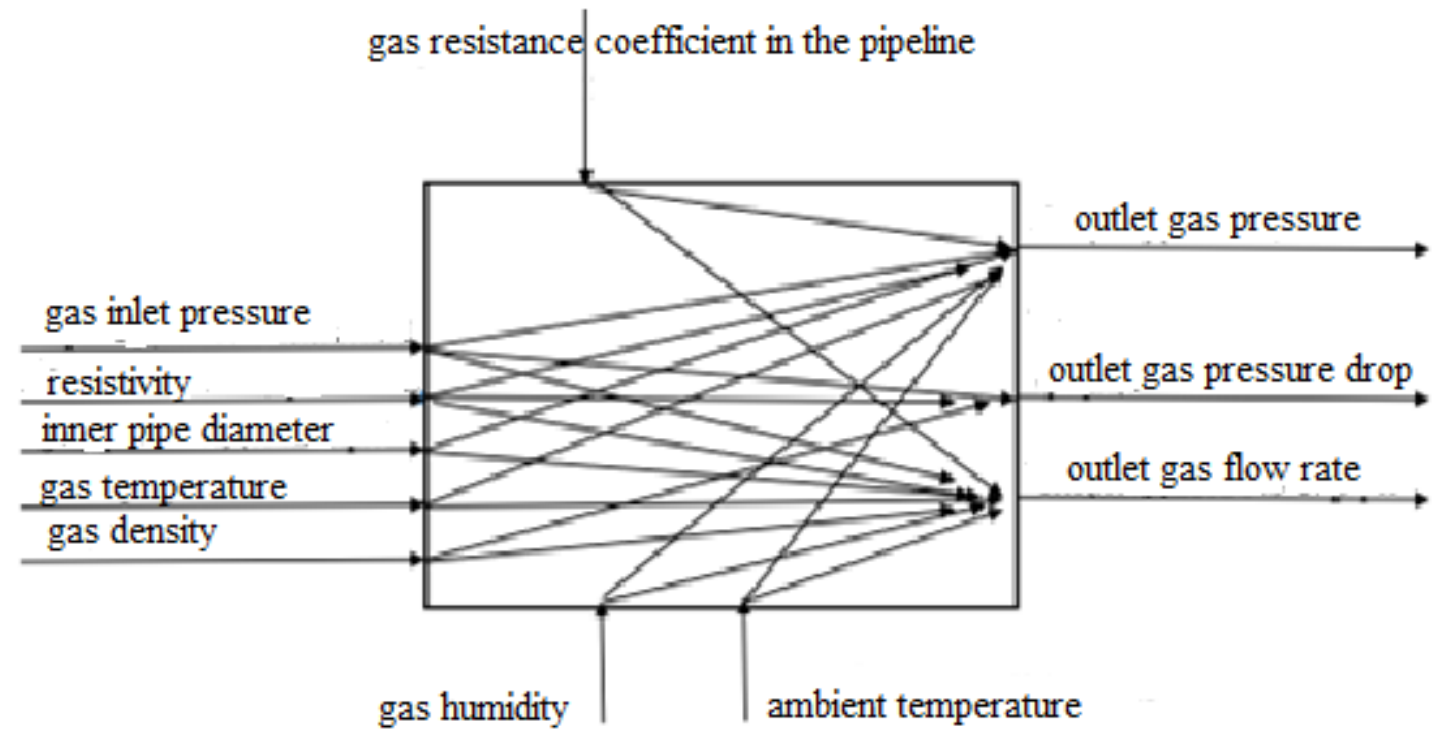

Figure 1. Information model of the gas transportation system.

Natural gas flow is described by the following system of differential equations:

$$
\left\{\begin{array}{c}
\frac{\partial \rho}{\partial t}+\frac{\partial}{\partial x}(\rho v)=0 \\
\frac{\partial}{\partial t}(\rho v)+\frac{\partial}{\partial x}\left(\rho v^{2}\right)+\frac{\partial \rho}{\partial x}+\rho g \sin \alpha+\frac{1}{4 r} \lambda \rho v|v|=0 \\
\frac{\partial}{\partial t}\left(\rho \varepsilon^{(y \partial)}+\rho v\left(\frac{v^{2}}{2}+h^{(y \partial)}+g H\right)\right)=-\frac{2}{r} K\left(T-T_{\mathrm{TM}}\right),
\end{array}\right.
$$

where $\mathrm{P}$ is the pressure in the gas pipeline; $\mathrm{T}$ - gas temperature, $\rho$-gas density; $v$ - gas flow rate;

$\mathrm{x}$ - the coordinate of the length of the gas pipeline; $\mathrm{t}$ - time; $\mathrm{d}$ - is the inner diameter of the pipe;

$\lambda$ - coefficient of hydraulic resistance; $\boldsymbol{\alpha}$ - the angle of rotation of the gas pipeline in relation to the horizon; $\mathrm{H}$ - the height of the gas pipeline relative to sea level; $\varepsilon$ - comparative gas resistance,

$\mathrm{h}$ - is the comparative enthalpy of the gas, that is, the function of the state of the thermodynamic system $\mathrm{H}$ is equal to the sum of the internal energy $U$ and the derivative of pressure $\mathrm{P}$ and volume $\mathrm{V} . \mathrm{H}=\mathrm{U}+\mathrm{PV} . \mathrm{g}-$ the acceleration of gravity, $\mathrm{T}_{\mathrm{tm}}$ - the ambient temperature, $\mathrm{K}-$ the coefficient of heat release into the environment [4].

Problems of mathematical modeling of the main transportation of natural gas. The main initial indicators when planning long-term operating modes of the gas transmission system (GTS) are the volumes of gas production and consumption. Depending on factors that are very difficult to predict, gas demand can lead to signifi- cant changes. Firstly, this is the weather conditions - natural gas, compared to the cold winter time, is significantly reduced in hot seasons [4].

Secondly, it is the rate of economic growth of countries with different economic and political-economic conditions, for example, the rate of economic growth of countries consuming energy resources. A certain degree of unreliability of the condition of pipes and power equipment plays an important role in the planning of medium and short-term modes.

Let us consider the system of main gas transportation in which some parameters are not unreliable, we will use a fuzzy expression for these parameters. The following is not known for certain:

- gas consumption at the inlet and outlet of the system;

- coefficients of hydraulic resistance of pipes;

- maximum compressor power;

- production rate of wells.

All these values can be designated as fuzzy numbers, the membership functions of which are determined by expert methods. Simplifying calculations only without loss of generality, we use triangular membership functions for all fuzzy values:

$$
\mu_{j}(x)=\left\{\begin{array}{c}
1, \text { агар } x \leq x_{j, \text { min }}, \\
\frac{x_{j, \text { max }}-x}{x_{j, \text { max }}-x_{j, \text { min }}}, \text { агар } x_{j, \text { min }} \leq x \leq x_{j, \text { max }}, \\
0, \text { агар } x_{j, \text { max }}<x .
\end{array}\right.
$$

At the inlet of the GTS, the flow rate is indicated as a fuzzy number $\left(x, \mu_{q}(x ; p)\right)$. The variable $\mathrm{p}$ is taken as a 
parameter: we will assume that for each p there corresponds a fuzzy flow rate. The computational module converts the membership function (MF) of the flow rate $\left(x, \mu_{q}(x ; p)\right)$ into the MF of the flow rate $\left(x, \mu_{q}^{-}\left(x ; p^{-}\right)\right)$at the output. The intersection of fuzzy sets is determined by the formula $\mu_{A \cap B}(x)=\min \left(\mu_{A}(x), \mu_{B}(x)\right)$, using the operator $\mu_{q}(x ; p) \rightarrow \mu_{q}^{-}\left(x ; p^{-}\right)$taking into account that the coefficient of hydraulic resistance $\left(x, \mu_{N}(x, p)\right)$ and $\left(x, \mu_{N}\left(x, p^{-}\right)\right)$fuzzy variables.

The $\mathrm{p}$-value in $\mathrm{KC}$ is expressed as follows:

$$
\bar{p}=\bar{p}_{K C}(\underline{p}, \underline{q}, N)
$$

and on transmission lines according to the following formula:

$$
\bar{p}=\bar{p}_{\text {лу }}(\underline{p}, \underline{q}, \lambda) .
$$

$p$ on the transmission line is calculated exactly, and in the CS it is chosen by the optimal method, since the $\mathrm{CS}$ power $\mathrm{N}$ is a variable of the control action [5].

The solution was found by the ordered search method (dynamic programming). In the process of dynamic application, the inlet pressure given to the outlet flow rate $\left(x, \mu_{q}^{-}\left(x ; p^{-}\right) M F\right.$ is determined to ensure the maximum level of membership in this inlet pressure:

$$
\mu_{\bar{q}}(x, \bar{p})=\min _{\underline{p}}\left\{\mu_{\underline{q}}(x, \underline{p}), \mu_{N}(x)\right\},
$$

in addition, in the operation of obtaining the maximum (3), $p, N, p$-values must be related by relation (1).

In practice, the situation is complicated even by the lack of partial or complete information on the statistical characteristics of the noise. Therefore, to solve the estimation problem it is proposed to use the theory of fuzzy sets. time:

Consider a nonlinear dynamic system with discrete

$$
x_{k+1}=F_{k}\left(x_{k}, w_{k}\right), k=1,2, \ldots
$$

for this system, its size and state are interrelated:

$$
z_{k}=H_{k}\left(x_{k}, v_{k}\right)
$$

In these equations, the index $\mathrm{k}$ corresponds to the $\mathrm{k}$-moment of time;
$F_{k}, H_{k}$ - k -nonlinear functions of suitable arguments;

$x_{k}$ - dynamic state of the system;

$w_{k}$ is a fuzzy disturbance defined for each time instant $\mathrm{k}$ of the $\mathrm{MF} \mu\left(w_{k}\right)$;

$v_{k}$ - measurement error with a known membership function $\mu\left(v_{k}\right)$.

To determine the best estimate of the state $x_{k}$ at time $\mathrm{k}$ for a given expression for the MF $\mu\left(x_{k} \mid \bar{z}_{k}\right)$, we use the formula:

$$
\mu\left(x_{k}^{0}\right)=\max _{x_{k}} \mu\left(x_{k} \mid \bar{z}_{k}\right) .
$$

In the presence of some conditional MF $\mu\left(x_{k+1} \mid \bar{z}_{k}\right)$, the optimal point estimate of the current state of the system for the moment $(k+1)$ can be determined as follows:

$$
\mu\left(x_{k+1}^{0}\right)=\max _{x_{k+1}} \mu\left(x_{k+1} \mid \bar{z}_{k}\right) .
$$

For fuzzy constraints $C_{k} \subset U$ characterized by the MF $\mu_{C_{k}}\left(u_{k}\right)$, a control action $\mathrm{u}_{-} \mathrm{k}$ is introduced at each time instant $\mathrm{k}$ and it is assumed that the initial state $x_{0}$ is given. Let's say there is a fuzzy goal $\mu_{G_{N}}(x)$ (x) that needs to be achieved in time $\mathrm{N}$ [5].

\section{Conclusion}

Optimally known control actions $u_{0}^{0}, \ldots, u_{N-1}^{0}$ can be defined, [54]:

$$
\begin{array}{r}
\mu_{G}\left(u_{0}^{0}, \ldots, u_{N-1}^{0}\right)=\max _{u_{0}, \ldots, u_{N-2} u_{N-1}}\left\{\mu_{C_{0}}\left(u_{0}\right) \wedge \ldots \wedge\right. \\
\left.\mu_{C_{N-1}}\left(u_{N-1}\right) \wedge \mu_{G_{N}}\left(F\left(x_{N-1}, u_{N-1}\right)\right)\right\} \\
=\max _{u_{0}, \ldots, u_{N-2}}\left\{\mu_{C_{0}}\left(u_{0}\right) \wedge \ldots \wedge \mu_{C_{N-2}}\left(u_{N-2}\right) \wedge\right. \\
\left.\mu_{G_{N-1}}\left(x_{N-1}\right)\right\}, \\
\mu_{G_{N-1}}\left(x_{N-1}\right)=\max _{u_{N-1}}\left\{\mu_{C_{N-1}}\left(u_{N-1}\right) \wedge\right. \\
\left.\mu_{G_{N}}\left(F\left(x_{N-1}, u_{N-1}\right)\right)\right\},
\end{array}
$$

here the function $\mu_{G_{N-1}}\left(x_{N-1}\right)$ can be considered as the MF at time N-1, which is induced by the final goal $G_{N}$ at time N.

Thus, it is possible to find an effective exact control $u_{k}^{0}$ at an arbitrary time instant $\mathrm{k}$ knowing the current nonlinear state $\mu\left(x_{k}\right)$, the nonlinear constraint $\mu_{G_{k}}\left(u_{k}\right)$, and the induced nonlinear target $\mu_{G_{N}}\left(u_{N}\right)$ based on (6), (7).

\section{References:}

1. Gostev V.I. Nechetkie regulyatori v sistemax avtomaticheskogo upravleniya / V.I. Gostev - K.: «Radiomator», 2008. $972 \mathrm{~s}$.

2. Dmitriev V.M., Gandja T.V., Istigecheva Ye.V., Klepak I.Ya. Intellektualizatsiya upravleniya texnologicheskimi protsessami na uglevodorodnix mestorojdeniyax. Tomsk: V-Spektr, 2012. - $212 \mathrm{~s}$.

3. Kulik V.S. Optimizatsiya rejimov transportirovki prirodnogo gaza po sistemam magistralnix gazoprovodov v usloviyax neopredelyonnosti isxodnix dannix: Dissertatsiya kandidata texnicheskix nauk: 05-13-18. - M., 2015

4. Siddikov I.X., Shomirzaev B.U. Gas Pressure and Flow Control Algorithm in Main Gas Pipelines Using the Fuzzy Logic Apparatus // International journal of advanced research in science, Engineering and technology. India 2019, Vol. 6, Issue 8,

5. Zibert G.K., Sedix A.D., i dr. Podgotovka i pererabotka uglevodorodnыx gazov i kondensata. Texnologii i oborudovanie. Spravochnoe posobiem- M.: OAO "Nedra-Biznessentr", 2001. - 316 s. 